\title{
Social service provision dilemmas faced by Social workers in the management of Zimbabwean welfare organizations: a desk review.
}

\author{
Denford Gudyanga (MSc SW, HSW), University of Zimbabwe - College of Health Sciences
}

\begin{abstract}
The provision of Zimbabwean social services ranges from public health to education and housing. Globally, these services have been put in place by governments and stakeholders to promote citizens' welfare. Through a desk review, this paper briefly discusses dilemmas social work managers face daily. These include matching clients' needs to government ideology underpinning service provision, negotiating with overarching political influence and lack of adequate resources as well as ethical dilemmas stemming from a profession's code of conduct. The paper ends by recommending that Zimbabwean social workers should aspire for high management and or legislative positions which empowers them to make meaningful policy decisions that ensure the promotion of the dignity of service users. Further, lobbying legislators and social service funders to put the needs of service users first should be an ongoing cause to champion social justice and equity within the Zimbabwean social service sector.
\end{abstract}

\section{Keywords}

Zimbabwe, Social work dilemmas, Social services, management

\section{Introduction}

As a country, Zimbabwe fluctuates between the socialist and capitalistic ideology. As a result, its social services are a mixed bag of an open market at the same time taking upon itself the burden of providing social services such as mental, sexual, and reproductive health free of charge. Within every social service agency, there are managers tasked with overseeing service provision to clients as per the agency's mandate. Mayers et al (1994, p. 1) cite Miringoff (1980) who defines management "as a system of interacting parts aimed at effective and efficient provision of services. As such Fayol's (1916)'s roles of a manager entail that managers be tasked with obtaining, planning, controlling, and disbursements of 
human, financial and technical resources to ensure timely, efficient, and effective social service provisions to society. More often than not, managers are faced with difficulties in balancing the ideals and realities in the provision of social services in Zimbabwe.

\section{Why dilemmas in management?}

Dilemmas in management arise from the existence of two pathways that can be taken in the provision of social services. McAulife (2005) posits that choosing between two or more undesirable alternatives is therefore the most common challenge social work managers are faced with on a day-to-day basis. According to Mayers et al (1994), managers are tasked with planning, organizing, allocating, controlling, evaluating, and leading. Executing these and other roles requires managers to be highly adaptive, keeping abreast of current global management trends and flexibility such as being artistic, scientific, and grounded within their profession's board of knowledge and values. Most importantly it calls for managers who are out of the box thinkers and visionaries who can strategically steer the organization into the future (Ansoff and McDowell, 1990). Managers must also be able to blend a variety of management theories such as max weber's theory of bureaucracy, Fredrick Taylor's scientific management, Henri Fayol's administrative theory, and Elton Mayo's human relations perspective among others. A skilful blend of the above tenets will go a long way in assisting a manager in the efficient and effective provision of social services even in the face of service provision dilemmas as outlined by the following themes.

\section{Government's ideologies versus resource constraints}

Government ideologies influence the provisions of social services in every country. Soon after independence in 1980, Zimbabwe adopted a socialist ideology where social services were provided on a universal need basis or growth with equity principles (Shizha and Kariwo, 2011). Education was free and most social services were provided free of charge or required very nominal user fees to be provided. It was the prerogative of the Zimbabwe government to avail such services to its citizens from the national treasury. Examples include free primary education, setting up of the Zimbabwe Manpower Development Fund, free pre and neonatal health care, free mental health care, and sexual and reproductive health. However noble these free services may seem, in the face of a dwindling gross domestic product and an even smaller national budget, social service managers have to face the dilemma of balancing the government ideology and available resources. On paper, the government provides institutional grants to all residential care facilities for the mentally ill, 
senior citizens, and child protection centres. In reality, however, rarely is this money received by those institutions due to resource constraints within the government. Considering that such services are essential in every society, managers are then faced with a dilemma of either charging service user fees which violates national laws but keeps the social service organizations afloat or provides poor quality, intermitted, and ad hoc services and close shop when they run out of resources. Most social service providers have therefore chosen to stay afloat by charging contributory fees. Mental health services are free in Zimbabwe, however in the absence of medication; one is often if not always referred to a private pharmacy to purchase them when seeking treatment in state-owned health institutions. This is the compromise social service managers have resorted to. Rather than closing down an office for lack of resources, referrals are being made to where paid services can be accessed. Hence, McAulife (2005) highlights structural issues such as negotiating power, politics, and unresponsive laws that do not allocate enough resources as hindrances to effective social service provision and causes of serious ethical dilemmas for social workers. Across the country, most patients are opting to buying their medication and bringing it to the hospital to receive services thereby ensuring that clients continue to receive a semblance of quality care. This dilemma is also found among non-governmental organizations who when their funding ends have to negotiate between closing shop or offering the most minimal services to communities and stay afloat. Strategically steering organizations to safety in such difficult times is therefore the manager's chief duty. What should however not be overlooked is McAulife's (2005)'s viewpoint that what one social worker may see as a dilemma may not be a dilemma to the next social worker.

Whenever there is a clash between government ideology and the availability of resources for social service provision, there are often compounded issues of human capital loss. Managers are not only tasked with controlling material and intellectual resources but human resources as well. Brain drain, therefore, becomes every manager's nightmare as losing skilled and experienced human resources can be a shattering blow to the provision of high quality and efficient social services. The turn of the twenty-first century saw the exodus of hundreds of Zimbabwean Social Workers to Europe and America in search of greener pastures. Offices were left unmanned and mangers had to decide between closing down the offices or recruiting unqualified cadres to fill up the vacant posts which is what has become the norm in Zimbabwe. One example is the Department of Social Services in the Government of Zimbabwe. The department was traditionally manned by social workers who were and still 
recognized by law as the most qualified cadres to manage the department, however, for the sake of service continuity, cadres from sociology, psychology, and political science had to take on the roles of social worker resulting in service quality deterioration within the department. The government is however attempting to remedy the situation through the provision of entry-level Social work education to non-Social work professionals within the Department of Social Services. Under the socialist ideology, professionals are not remunerated according to roles, experience, or skill but are all lumped up as opposed to remuneration within the capitalistic governments. As such managers need to motivate employees more as well as finding innovative ways to retain skilled labour within their organizations.

\section{Dealing with overarching political influence}

Max Weber's and Fayol's (1916)'s classical organizational theories posit that there is just one best way of managing an organization based on the hierarchy of offices and clearly defined roles for each office bearer and each employee being supervised by their superior. Even in organizations that are pro-human relations perspective, rigid bureaucratic rules and regulations are still in place to plan, organize, direct, coordinate, and control the operations of the agency. Most organizations, be it governmental, intergovernmental, or nongovernmental are high-breed organizations that embrace a little bit of each management principle. These organizations are more often than not influenced by national or international politics. Managers therefore are faced with a dilemma of having to negotiate between serving the actual needs of their clients at the same time fulfilling the mandate set by politics. Managers in the department of social services in Zimbabwe are often undermined by partisan politics that dictate who is the deserving and undeserving social service recipient instead of following the government gazetted means testing procedure. The same situation is found in local authorities were housing units or residential stands are allocated based on the strict dictates of the board of directors or politicians, a situation which compromises quality service provision and short changes the rightful and or deserving service users. Zaviršek et al (2010) therefore point out that social workers are often forced by national laws entrenched in politics to enforce social service provisions that discriminate the most deserving and promoting the very social injustices they are keen on addressing as a profession.

Political interference in service provision is not only true for local government-funded services but international social services as well. International funding for social service 
always comes with stringent preconditions that must be satisfied by managers. These measures do not always consider the needs of service users. Examples include the use of photographic evidence to show that services have been received. As a social worker, there are values such as the client's self-determination and principles of confidentiality that must be upheld. Deciding to uphold the said social work values will result in losing future or even current donor assistance, at the same time leaning towards donor preconditions violets client's dignity. Examples include agencies that often use pictures that depict people in their most abased state as a way of luring in financial assistance from well-wishers. Whether these service users would have consented to be used as case studies does not validate the infringement of social work values and ethics. Social work managers, therefore, face a grave risk of being situated and assimilating these tendencies of violating client's dignities due to their need for employment and by extension satisfying the demands of their international or national benefactors at the expense of the client's dignity.

\section{Change management dilemmas}

Negotiating between the changing social services needs of clients in the face of archaic organizational or national policies is a growing headache for most managers. Organizations often adapt to technological changes very slowly. An example is that of the Registrar's department within the government of Zimbabwe. The same method of issuing out birth certificates used 10 years back is still in use and the same bottlenecks found within the system are still in existence. Whilst other countries have already embraced electronic systems within government departments to ensure efficient and quality service delivery, in most districts, the government of Zimbabwe still relies on its archaic and slow analogy system. Strategic management of such social service organizations is therefore next to impossible as at times meaningful changes are made at the highest level to which the manager may not have access to, lobbying, therefore, becomes crucial. Other social work managers working outside of government providing social services have realized the need to manage change for organizations to remain relevant in today's society. For example, there is a need for managers to initiate and embrace creativity and innovation. A question, therefore, is, "should we adopt the use of computers to provide efficient, cost-effective services through the digital platform that removes the personal human touch or rapport?" If the answer to the above question is a yes, this then entails retrenching employees which defeats the whole purpose of social service providers such as social security in the first place. Organizations such as ChildLine Zimbabwe which provide telephone counselling services within their call centres 
are slowing becoming obsolete should they not embrace virtual call centres that have merged with social media platforms. Big organizations such as banks, universities, hospitals, and embassies have moved their call centres to the internet of things. Calls can now be made to the call centres from Facebook, WhatsApp, and other internet-based platforms. Beer (1985) therefore echoes that it is crucial for managers to strategically position their organizations to respond to the global changes. However, when decisions are made by conservative executives or policymakers who do not appreciate the need for change, the result is what can be witnessed in the Zimbabwe social service organizations where most hospitals do not have toll free lines or an online presents yet most of their service users use such platforms on a day to day basis. Social work managers, therefore, have to lobby the higher powers within their originations to realize the need for such changes even at the risk of losing their jobs which in itself is a dilemma.

\section{Social work profession's ethical dilemmas}

As a profession, Social Work has a set of principles underpinning the work of each practitioner regardless of their practice setting. Biestek (1961) outlines these principles as; purposeful expression of feelings, acceptance, individualization, non-judgemental attitude, client's self-determination, confidentiality, and controlled emotional involvement. In social service provision, social work managers, therefore, struggle to balance between the role of managing an organization and that of being a champion of social justice and change. This is especially difficult when implementing change management within organizations. Nongovernmental organizations often focus on areas they can receive funding as opposed to areas that communities need more assistance with. For example, when HIV/AIDS was not recognized as a global health threat, very few if any organizations were in that field, however, when funding was poured into the area, hundreds of local projects were initiated. As a social worker, one is ethically bound to assist in linking clients with available resources and ensuring that they benefit from resources within their communities. As a manager, however, one has to allocate resources both human and financial to where agency gaols can be met. This entails turning down clients who don't fit agency criteria even if they are deserving of such a service. If an organization is providing reproductive and sexual health services to commercial sex workers, only that group is to benefit and every other client outside of that group should and must be denied service. Social work managers are therefore faced with the dilemma of having to allocate vast resources to a few in-group members who fit into the agency mandate, resources that would have otherwise benefited the wider community. 
Conforming to social pressure or remaining true to oneself is a problem some Zimbabwean Social workers have to grapple with. Such as being excluded from the list of social service beneficiaries yet they too have social needs such as housing and health care. In the face of difficulties being experienced in the Zimbabwean housing sectors, there is a temptation for managers to put their needs above those of the clients they serve. Issues of corruption are rife in the Zimbabwean social service sector. Such as managers who are corruptly allocating housing units to their relatives or selling otherwise freely provided social services in various government departments. The dilemma for managers is therefore whether to conform to this prevailing culture of abuse of office or remain true to their duty. As a social work manager, one has to uphold his or her professional and ethical principles and set a good example to those whom one is managing. Especially as Social work principles foster the linking of society with available resources. As well as ethically managing these resources for continuity and sustainability as a crucial ethical requirement for all social work managers to uphold.

\section{Collaborative dilemmas}

Managers do not work alone but within the context of organizations that employ professionals from various disciplines. Each profession has its own set of management principles and goals regardless of the universally acclaimed management theories that are cross-cutting within professions. Mintzberg's (1975)'s management tenets of leading, mobilization, allocation, monitoring, and negotiating in the use of resources by an Administrator is different from the approach taken by an Accountant, and more so different from the way a social worker would go about his or her duties. It is within the context of each profession's body of knowledge that meaning and goals of management are derived and areas of management expertise are acquired. The goal of social work has always been that of empowerment (Biestek, 1961) and this goal can be evidenced in any role that a social worker assumes, this is equally true for every professional. In social service provision, such a professional orientation creates dilemmas for a manager in that either one has to follow their professional orientation or the general management goals of the organization which entails optimum and effective service provision at whatever cost. This dilemma is even more compounded by managers working with people from different professional backgrounds who also have similar or senior managerial roles. Hence, Drucker (1989) rightfully argues that the art of collaboration, ability to negotiate, and flexibility is the key to navigating such 
situations. It is from the above dilemma that social workers have often questioned the authenticity of being managed by non-social workers in social service organizations. Hence most professions now advocate being managed by their kindred spirit as opposed to a manager from a similar or different profession as conflicts of interest are inevitable in such situations.

\section{Conclusion and recommendations}

Ranging from ethical dilemmas, change management, and political influence underpinning the management of social service provision in Zimbabwe, social workers are faced with a myriad of problems in their execution of management duties. They have a dual duty, to their organization as well as to their clients. Negotiating the decision of whose needs to meet is a huge social work practice dilemma as has been briefly highlighted by this paper. It has also been highlighted that what one manager might view as a dilemma may not be a dilemma to the next manager. It is therefore recommended that social workers should aspire for high management and or legislative positions which would enable them to make meaningful policy and other decisions to ensure that the dignity of service users is upheld. In the meantime, lobbying legislators and social service funders to put the needs of service users first should be an ongoing cause to enable championing of social justice and equity within the Zimbabwean social service sector. 


\section{References}

Ansoff, H. I., and McDowell, E. J. (1990). Implementing strategic management ( $2^{\text {nd }}$ ed.). Hemel Hempstead: Prentice Hall.

Beer, S. (1985). Diagnosing the system: for organisations. Chichester: Wiley.

Biestek, F. (1961). The Casework Relationship. London: George Allen and Unwin.

Drucker, P. F. (1989). The practice of management. London: Heinemann.

Fayol, H. (1916). Administration industrielle et générale. In Bulletin de la Société de l'Industrie minérale. Paris: Dunod.

Mayers, R S, Souflee Jr and Schoech, DJ (1994). Dilemmas in human services management: Illustratiive Case Studies. Springer Publishing Company.

McAulife, D. (2005). I'm Still Standing: Impacts and Consequences of Ethical Dilemmas for Social Workers in Direct Practice. Journal of Social Work Values and Ethics. Griffith University.

Mintzberg, H. (1975). The manager's job: folklore and fact. Harvard Business Review JulyAugust, 49-61.

Shizha, M. and Kariwo, M.K. (2011). Education and Development in Zimbabwe A Social, Political and Economic Analysis. Rotterdam, Sense Publishers.

Zaviršek, D., Rommelspacher, B. and Staub-Bernasconi, S. (2010). ETHICAL DILEMMAS IN SOCIAL WORK. International Perspective. Faculty of Social Work, University of Ljubljana. 